\title{
"To liberate or to regulate: balanced approach to bank-oriented financial system transformation in developing countries"
}

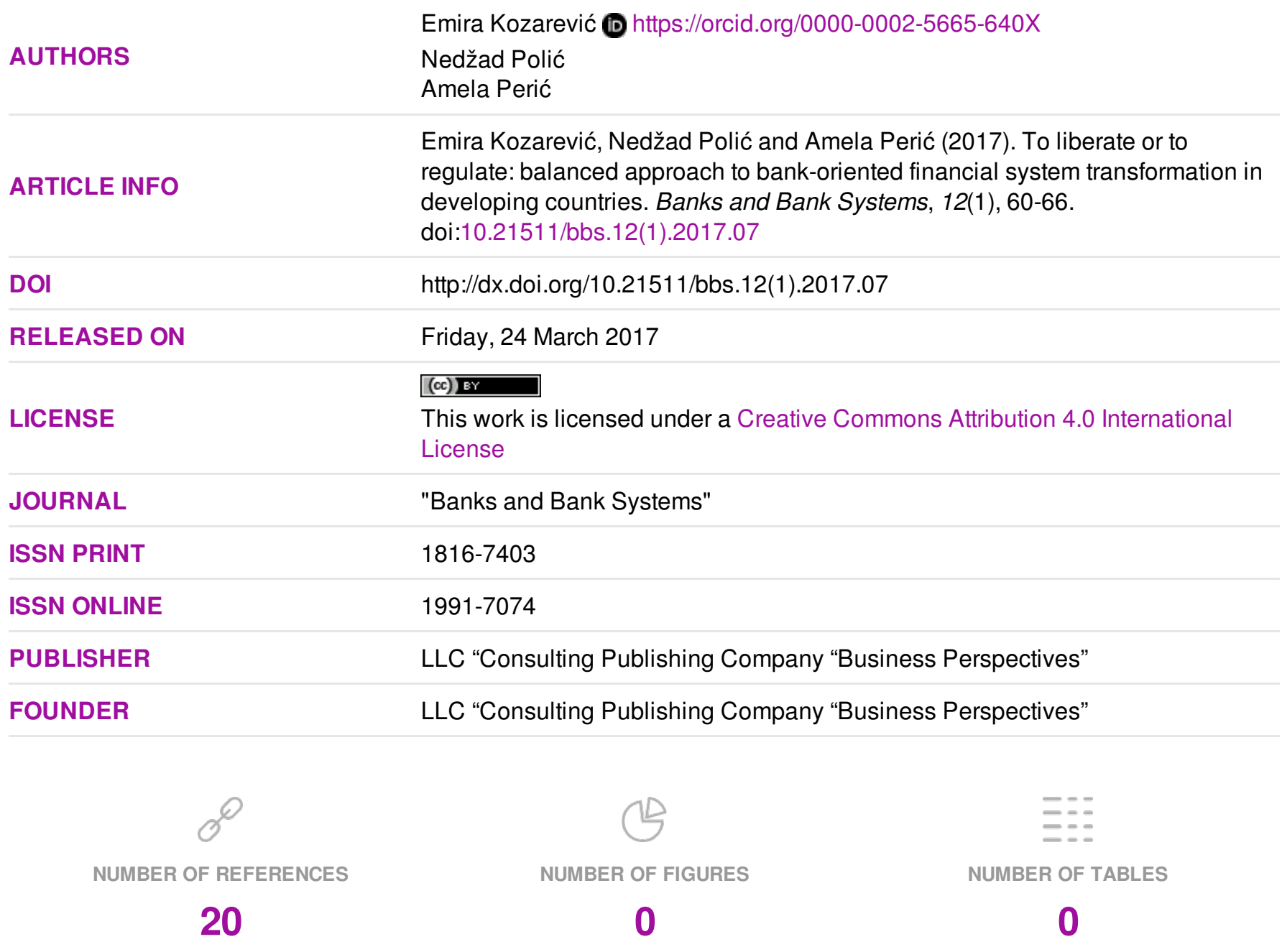

(C) The author(s) 2023. This publication is an open access article. 


\title{
Emira Kozarević (Bosnia \& Herzegovina), Nedžad Polić (Bosnia \& Herzegovina), Amela Perić (Australia) \\ To liberate or to regulate: balanced approach to bank-oriented financial system transformation in developing countries
}

\begin{abstract}
A stable, transparent financial system inspires confidence among investors and supports the overall economic growth. Inflexible regulation tends to slow down economic progress, making countries less attractive to investors.

Economies with bank-oriented financial systems tend to be less attractive to investors, so their long-term goal is to demonstrate flexibility through liberalization, attracting new investors and ensuring survival in highly competitive and unforgiving global conditions. Liberalization success is even more essential for developing countries and their efforts to open the borders for capital flows and attract new investments. While financial liberalization affects all sectors of the economy and directly influences growth, it does not guaranty it. The removal of financial restrictions could affect capital distribution, increase volatility, create challenges for banks, etc. To support the liberalization efforts, it is very important to understand the nature of banking business, criticality of transparent and effective regulatory framework, as well as the expectations of potential investors.
\end{abstract}

The main goal of this paper is to discuss the process of financial liberalization in developing countries and motivate the policy makers to consider available lessons when creating their balanced approach to financial (de)regulation processes towards financial development and integration in the global financial landscape.

Keywords: financial liberalization, financial regulation, economic development, developing countries. JEL Classification: G18, G21, G28.

\section{Introduction}

Financial system is a very important element of every economy. Financial system mobilizes savings and allocates loans, stimulating new investments that support economic growth, while a regulatory framework sets the rules and controls activities within the system, providing stability for investors. Inflexible rules and regulations tend to slow down the economic progress, making a developing country less attractive for new investors and closed to financial innovations.

Deregulating steps can involve changes to interest rates determination, restructuring of financial institutions, abolishment of direct loans allocation practices, promotion of prudential regulation, establishment of new banks/multi-facets financial institutions, etc.

While interest rates are not the sole factor associated with investments, deregulated interest rates and market volatility could still create serious challenges for banks and lead to the increase in non-performing loans.

The key to success is in determining the appropriate balance between the level of financial liberalization and sufficiently flexible and effective regulatory

(c) Emira Kozarević, Nedžad Polić, Amela Perić, 2017.

Emira Kozarević, Associate Professor, Tuzla University, Department of Finance and Financial Policy, Bosnia \& Herzegovina.

Nedžad Polić, Associate Professor, Zenica University, Department of Finance \& Hifa oil d.o.o., Executive Director, Bosnia \& Herzegovina.

Amela Perić, Lecturer, University of Technology, Sydney, Master of Project Management, Australia.

This is an Open Access article, distributed under the terms of the Creative Commons Attribution 4.0 International license, which permits unrestricted re-use, distribution, and reproduction in any medium, provided the original work is properly cited. framework that will support economic growth and maintain investor confidence. Therefore, the main goal of this paper is to analyzes and critique the process of financial liberalization in developing countries and to motivate the policy makers to consider available lessons when creating their balanced approach to financial liberalization and regulation processes towards financial development, openness, and integration in the global financial landscape.

The paper is structured across the following sections: succinct theoretical background into financial liberalization, literature review, and analysis of financial liberalization in the light of global financial crisis, followed by summary.

\section{Theoretical framework}

Before a progress can be made with regards to liberalization or transformation of banks or other financial institutions, significant changes are necessary in terms of government-imposed financial regulatory rules. The push for market liberalization was getting a strong momentum in the $19^{\text {th }}$ century in Europe as part of the overall movement for civil and political liberties. The main reason for the strong-hand approach to market regulation in the first place was to ensure the stability of the financial system, as well as to reduce risk through restriction of competition between financial institutions. These measures had one aim - creation of a stable and reliable financial system. This approach resulted in significant segmentation of the system, as certain types of financial institutions were licensed to operate only in a particular segment of the market. 
Late 1970s and 1980s saw strong resurrection of liberalization ideas across the world and their implementation in many leading countries in the world. For example, UK government led by Margaret Thatcher introduced deregulation and privatization program, where some of the largest companies previously owned by government were privatized. In the US, Ronald Reagan made significant deregulation steps in various areas of economy, most notably in transportation (Cooper, 2012, pp. 120-125).

Over the years, the control of interest rates was gradually reduced and, in some countries, completely abolished, allowing for determination of interest rates solely on the basis of market methods. Since deregulation also includes abolition of restrictions that mandates narrow specializations of financial institutions, the new market conditions open the path for ownership and operational restructuring of financial institutions in line with optimum structure for effective functioning within an integrated financial markets platform (Ćirović, 2001, pp. 12-13).

Increased competition between banks and other financial institutions significantly changed the financial landscape from previously monopolistic and restricted conditions to a new state of increased rivalry (Canals, 1997, p. 327). There are various measures that can be actioned at reducing the degree of both internal and external regulatory control over institutions, instruments, and activities (Chandrasekhar, 2006, p. 983).

Ghosh (2005, pp. 2-3) identified a set of internal and external measures associated with deregulation. The following are some of the mentioned internal measures:

- reduction or removal of interest rate controls, with central bank continuing to influence rate movements through its operations;

- state withdrawal from financial intermediation;

- development banks conversion into regular banks;

- privatization of the publicly owned banking system;

- relaxation of listing and market rules;

- greater freedom to intermediaries such as brokers;

- relaxed controls over the investments that can be undertaken by financial agents;

- removal of "Chinese walls" between banking and non-banking activities;

- development of additional market instruments, supported by relaxed governing rules.

In terms of external financial liberalization, the measures are mostly associated with the changes in the exchange control regime. They involve set of reforms enabling convertibility for current and capital accounts transactions and trade liberalization.
Some of capital account liberalization measures include as follows:

- allowing foreign residents to hold domestic financial assets in the form of debt or equity;

- allowing domestic residents to hold foreign financial assets;

- allowing foreign currency assets to be freely held and traded within the domestic economy.

The latter is one of the most extreme measures only implemented in a very few economies, for example, some Latin American countries officially adopting US currency as legal tender (dollarization) (QuispeAgnoli, 2002, p. 2).

For more than two decades, financial liberalization in developing countries has been seen as an important part of an economic policy package promoted by the "Washington Consensus"1. Mostly, the liberalization movement in those countries has been associated with measures that are designed to make the central bank more independent, remove financial restrictions by decontrolling interest rates and allowing financial innovation, while reducing directed and/or subsidized credit and allowing greater freedom in terms of external flows of various forms of capital.

Numerous financial crises around the world have provided valuable lessons and increased the overall awareness for developing countries when it comes to coordinated regulation and supervision of financial institutions. Globally, we can see the overall harmonization of standards for financial institutions, primarily through Basel agreements (Capital Accord or Basel I, 1988, Amendment of Basel I or "BIS 98", 1996, and the New Capital Accord, or Basel II, 2004).

It is important to understand the increased exposure to risk associated with financial liberalization. Better understanding of lessons associated with this process means more effective measures in risk management and higher chances for success.

Financial fragility and deflationary impacts are some of the common risks facing developing countries when going through liberalization process. Greater freedom to invest, including decisions to invest in more sensitive sectors such as real estate and stock

\footnotetext{
1 The syntagm "Washington Consensus" was originated by John Williamson in 1990 and referred to the lowest common denominator of policy advice being addressed by the International Monetary Fund and the World Bank to Latin American countries as of 1989. These policies included as follows: fiscal discipline; a redirection of public expenditure priorities toward fields offering both high economic returns and the potential to improve income distribution, such as primary health care, primary education, and infrastructure; tax reform (to lower marginal rates and broaden the tax base); interest rate liberalization; a competitive exchange rate; trade liberalization; liberalization of inflows of foreign direct investment; privatization; deregulation (to abolish barriers to entry and exit); secure property rights. Nowadays the phrase "Washington Consensus" is often seen as synonymous with neoliberalism and globalization (http://www.cid.harvard.edu/cidtrade/issues/ washington.html, accessed: 16/5/2015).
} 
markets, ability to increase exposure to particular sectors and individual clients, accompanied by an increased regulatory forbearance all lead to increased exposure to risks of financial failure.

Liberalization also creates a risk of deflationary bias in government policy, reinforced by high costs of debt in a situation in which real interest rates typically substantially exceed growth rates. With low regulation of financial sector, the market will determine the allocation of investible resources and this will direct the capital towards more profitable sectors of the industry, meaning negative impact on employment-intensive sectors such as agriculture and small-scale enterprises. This, in turn, has major social effects in terms of loss of employment and more volatile material conditions for most citizens (Ghosh, 2005, pp. 11-14).

The financial crisis of 2007-2009 is considered the most severe since the Great Depression of 19291933. Many US financial institutions defaulted or disappeared or were taken over, while some were saved and survived thanks to support from the Federal Reserve Banks and the Treasury (Thomas, Palacios \& Stoll, 2013, p. 1).

Financial liberalization and economic opening of China provides some valuable lessons for the developing countries who wish to avoid the crisis and find the best way to balance liberalization and globalization efforts with risk management. China experience has to be put in the context of overall reform from a centrally planned towards a market-based economy - the process that has been ongoing for two decades.

However, the experience of financial liberalization in many countries suggests that the road towards financial globalization can be risky and often dangerous. While there are substantial long-term benefits from a market-based and globally integrated financial system perspective, we must not forget the risks and costs associated with such changes. The transition process from financially underdeveloped and closed to a financially open, globalized economy creates serious impacts on economic, social, and political elements. These impacts and risks need to be understood, considered, and managed. The status $q u o$ is a costly option, too, so, the best approach is to understand the transition process and learn from available lessons and experiences.

\section{Literature review}

While deregulation activities are recognized as the key steps in the economic liberalization, we can also find consistent messages in the literature that are highlighting the risks associated with the transition from highly regulated and controlled market to a liberated and globally integrated economic setting.
Wyplosz (2001, pp. 1-22) conducted a research into hazards associated with financial liberalization. He studied the liberalization experience on a sample of 27 countries (both developed and developing economies), attempting to identify whether exchange rate instability and the possibility of culmination into a full-blown currency crisis is a standard outcome. The results showed that the effects of financial liberalization are considerably more destabilizing for developing countries that for already developed economies. The results indicated that liberalization, while desirable from a long-term perspective, is highly risky in the short to medium run. The chances of success are increased with the right timing, appropriate political infrastructure, and an adequate setup for protection and assistance of those who might be negatively impacted by possible financial meltdowns and unexpected negative impacts.

Three other authors (Chen, Jonung \& Unteroberdoerster, 2014, pp. 1-44) identified a set of valuable policy lessons drawn from the Scandinavian experience that can be applied in China today. Scandinavian or Nordic countries (i.e., Denmark, Finland, Norway, and Sweden) are small, advanced market economies and welfare states. Their experiences ${ }^{1}$ associated with financial deregulation, financial crisis, and recovery during the period 1985-2000 provide highly useful lessons to any economy that is embarking on the uncertain journey of liberalization. At the beginning of this period, the financial system of Finland, Norway, and Sweden was bank-based, with banks (both commercial and savings banks) playing the major role as financial intermediaries. In short, the Nordic experience suggests that financial crises, triggered by a process of financial liberalization and integration (i.e., financial openness or elimination of cross-border barriers to financial flows, workings of unfettered financial markets), can be extremely costly in the short run for the overall society, taxpayers, owners of stocks and equities, as well as to politicians in power.

Chen, Jonung and Unteroberdoerster recognized some key lessons from the Scandinavian experience that can be useful to China, and to any other economies going through the liberalization process:

- Financial and process knowledge should be disseminated as widely as possible, to avoid dangers associated with the lack of understating the change.

- All policy makers and financial market participants should fully understand the behavioral and institutional linkages within the financial system and to the rest of the economy, as the workings of open financial markets are central to making financial liberalization successful.

\footnotetext{
Denmark was the exception - financial liberalization in Denmark involved less of a change in prevailing conditions than was the case in the other Nordic countries.
} 
- The reforms need to be properly sequenced in order to avoid negative chain reactions and interactions between various developments.

- The financial supervisory system should be reformed prior to or simultaneously with financial liberalization, giving a special focus to macroprudential issues.

- There are benefits of a flexible and cautious approach by liberalizing in small, but substantive steps, allowing time to learn from mistakes and provide the opportunity to backtrack or change approach when needed.

- Denmark experience shows that financial opening does not need to end in a deep crisis, as long as the right macroeconomic and regulatory policies are in place.

Some sub-Saharan countries embarked on a financial liberalization journey in late 1980 s, aiming to reverse ill-effects of financial repression with new economic policies. Fowowe (2013, pp. 1-37) surveyed 19 countries of this region during the 1980-2004 period. The results of his empirical research showed that financial liberalization had diverse and contrasting effects on savings, investment, and economic growth in that region. While the degree of success varied from country to country, overall expectations were not met and the financial systems remained shallow when compared to other regions. Most studies found that liberalization had largely positive impact on investment, while savings were less affected.

The liberalization experience of sub-Saharan African countries shows just how important it is that financial liberalization is carried out in a stable macroeconomic environment. Low and stable inflation, consistent and credible macroeconomic policies, fiscal discipline, and overall financial responsibility are essential prerequisites for successful and predictable transition process. This experience also prompts the need for significant reforms of institutions such as operational and political independence of central banks, legal and court systems improvements, establishment of asset and collateral agencies, as well as credit registries and credit reference bureaus, etc.

Young and Park (2013, pp. 561-581) conducted a research that focused on variations in national regulatory responses to the latest global financial crisis. They covered 30 different OECD countries and the period 2009-2012. Their results showed that state intervention during the global financial crisis was a necessary condition for a significant regulatory response, but that financialization played a more important role in terms of structural dominance of the financial system within an economy. The researchers' findings regarding the importance of financialization is consistent with a variety of available qualitative data associated with the behavior of financial regulators since the crisis.
A good example that supports this view is the recent international negotiations process associated with formation of the "Basel III Accord", the international regulatory policy-making forum for the newest minimum regulatory standards (BCBS, 2010). One of the most important negotiations items in the formation of Basel III was the equity capital holdings level requirement. It was interesting to see that highly financialized economies such as Switzerland, the UK, and the USA were in favor of higher Tier 1 equity capital levels, rather than supporting more relaxed standards. While the rest of the Basel Committee wanted a Tier 1 equity capital level set to $7 \%$, the regulators from those countries demanded a level of $9 \%$. While their suggestion for the higher level was not accepted (there is a consensus decision making rule within the Basel Committee), their behavior is consistent with the findings in the research data associated with highly financialized economies that underwent extensive state intervention during the crisis.

Similar behavior was also evident during Eurozone crisis of early December 2011, when UK negotiators supported the raise of capital requirements for retail banks as one of the ways to manage the crisis. All of them support the notion that there has been important shift within financial regulatory bureaucracies in highly financialized economies during the time of crisis, to more effectively control the recovery and manage risks. Whether or not regulatory policymakers are "puzzling" or "powering" their way through their post-crisis regulatory responses remains an open question, at least for now.

The experience from the Nordic and sub-Saharan countries, as well as the research of 30 OECD economies provides us with valuable lessons not only in understanding the post-crisis financial architecture and liberalization history, but also in understanding the dangers associated with financial liberalization and the importance of regulation as a tool for protecting the economy and managing risks. These lessons are a good reference tool for developing countries, especially their policy makers, regulators, official and private forecasters, economists, financial sector participants, and public at large. Financial literacy and high level of financial awareness, including proper learning from other countries, can help to create a balanced approach to financial system transformation in developing countries.

\section{Financial de/re-regulation before and through the global financial crisis}

Considering all earlier mentioned experience and research findings, the basic question we should ask is not whether to liberate or regulate the financial system of a developing country, but which financial controls should be chosen to effectively support liberalization, ensuring a stable and socially acceptable economic development. 
3.1. Before the global financial crisis. History teaches us that a solid, well-regulated and transparent financial system is an essential basis upon which liberalization efforts can be undertaken. Different economies will have their own specific conditions and history to consider, such as market size, political and economic organization and dynamics, degree of regulation, transparency, as well as political and economic control influence on internal and external market conditions.

China is a good example where a major export boom and rapid trade dependence have been associated with a financial system, which allows the government not only to systematically channel the credit in desired areas, but also to use this as a major macroeconomic instrument to manage demand, risk, and business cycles smoothing. More importantly, the growing integration of China with the world economy has not been disadvantaged by the absence of capital market integration, but instead the controlled credit was an important factor behind the huge export and industrialization growth (Ocampo, Jomo \& Khan, 2007).

There is also worth considering the argument that more controlled financial system encourages behaviors that thrive in non-transparency, such as corruption, secret deals, favors, and other factors of crony capitalism ${ }^{1}$, all of which can worsen the efforts of liberalization and handling of crisis. Relationship between cronyism and economic growth should be interpreted with reference to other factors such as demography, religion, colonial history, and cultural setting just as much as to individual policy makers and government strategies (Muzaffar, 2008, par. 7).

Greater openness about the direction of financial and other government decisions, increase of public accountability for financial transactions, promotion of free competition and market-driven development are the most effective ways in fighting non-transparent behavior. While corruption is an enemy of a free economy, the reality is that corruptive elements are characteristic to all types of financial systems, not only to those highly regulated, but also to those that are market-oriented. Economy free from the effects of crony capitalism requires genuinely competitive environment and free market space, where cronyism is a luxury that competitors just cannot afford (Macey, 2014, par. 7-13).

The history shows that it is not advisable that developing countries perform fast and complete implementation of all recommended internal and external measures for financial liberalization. The examples of those countries that have been successfully developed

\footnotetext{
1 "Crony capitalism" is a phrase describing an economy in which success in business depends on close relationships between business people and government officials.
}

from the nineteenth century onwards (and continuing to date) provide some key elements they all have in common and that are worth considering: they all had some degree (usually substantial) of directed credit and some controls on cross-border capital flows. For example, directed credit played an important role in countries like Japan and the Republic of Korea and was one of the key elements of the industrialization strategy in the $19^{\text {th }}$ century Germany as well as the early $20^{\text {th }}$ century United States.

Historically, various capital controls were proven as important in allowing the economic space required for industrializing countries to influence domestic investments and reduce unintended volatility in markets. Trade controls, together with the encouragement of import substitution were useful and necessary for late industrializers - something which is much more possible and likely when the capital account is also controlled. Policy makers see this as an old strategy that is no longer possible because of globalization and the reduced impact any individual national policy can make. It is often believed that developing countries can only follow the path of greater external economic integration and financial liberalization (Ghosh, 2005, pp. 15-16).

However, it is evident that there is a wide range of possibilities and methods of regulation or direction of capital flows. For example, various capital controls have been used by countries ranging from Chile and Colombia to Taiwan province of China and Singapore. There are also some more obvious direct controls, which regulate the actual volume of inflow or outflow in quantitative terms, such as those related to foreign direct investments and external borrowing by residents as well as to portfolio capital flows. There are also some indirect or market-based methods, which have been increasingly used to regulate capital movements, for example, a minimum residence requirement (of one to three years) on portfolio capital inflows and also on foreign direct investments.

In some countries, foreigners are prevented from purchasing domestic debt instruments and corporate equity, while some imposed a tax on foreign loans. Financial press tends to portray such controls as rigid and discouraging for investors. But the reality is very different - experience shows that these controls can be, and have been, used flexibly and altered in response to changing circumstances. These types of measures, if seen in context of the specific circumstances, often appear as a sign of proactive or reactive, flexible national policy to support economic growth. Controls over domestic financial activity and the regulatory role of the central bank need to be emphasized in order to prevent domestic financial crises and excessive cyclical volatility (Ghosh, 2005, pp. 16-17). 
It is interesting that before the global financial crisis (that originated primarily from the banking sector), the guidelines related to prudential regulation and supervision promoted by the Basel Committee on Banking Supervision were not as popular. In fact, they were often seen as pro-cyclical in their effects and too demanding with their requirements related to developed countries. But nowadays the Basel accords have become a strong and reliable reference for other financial institutions and their regulators (such as insurance companies), as well as widely implemented in developed and developing countries.

3.2. Consequences of the global financial crisis. Effective regulation of banks as financial intermediaries is important because of their systemic impact on economy and their role as deposit takers and loan providers. Although the Basel accords are intended for implementation by internationally active banks and in developed economies, the developing economies are often prompted (and forced) to implement the accords due to international regulatory and competition matters. It is useful to note that the banking crises in developing countries have generally exceeded $25 \%$ of GDP and are proportionately much larger in scale than the impact in developed countries (Dissanayake, 2012a, pp. 353-354).

The Basel accords were neither made for nor were intended to be applied in developing countries. As far as Basel III is concerned, it is also clear that the accord did not address developing countries concerns, as the accord uses indicators that are less suitable for assessing bank strength or soundness in developing countries.

While Basel III brought in some positive changes from the perspective of the developing countries, such as counter cyclic buffer and the new rules on assessing credit rating agencies, the structure of the accord still falls far short of the specific needs associated with developing economies. Therefore, it is necessary for regulators from developing countries to engage in discussions, which will be either truly global or that will specifically cater to the needs of the developing countries.

The Basel Committee could significantly contribute to the development of skills and expertise in developing countries. By establishing programs for sharing of technical skills and funding between countries, this issue will have greater chances for solution.

Also, Basel III addressed to some extent the role of credit rating agencies, but the content is not suitable for developing countries (i.e., they exacerbate the crowding out effect, due to the structure and practical effect of the rules). Unfortunately, many developing countries lack sophisticated internal rating mechanisms and capacity due to lack of skills and expertise.
Rojas-Suarez (2002, p. 36) recommended that developing countries approach their financial internationalization through an increased participation of foreign institutional investors in order not only to improve quality of capital and market discipline (by reducing concentration of wealth), but also to increase market access to necessary skills and expertise.

This is particularly useful for developing countries that are preparing themselves for compliance in line with Basel III. In order to increase market discipline, developing countries would also need to restructure their deposit insurance, taking into account the moral hazards associated with higher deposit insurance structures versus the large-scale losses. Besides, they need to consider the loss of confidence and impact on banks with regards to minimum deposit insurance. In terms of increasing the minimum capital requirements, it appears that many developing countries already impose much higher capital adequacy standards than required by Basel. For example, Argentina and Bosnia and Herzegovina as well already require $12 \%$, India $9 \%$, etc. It is anticipated that the newest higher standards (minimum capital requirements plus capital buffer, 10.5\%) will push most developing countries to increase their regulatory capital requirements in order to attract more deposits.

While the search for a regulatory standard which best fits the needs of developing countries should continue, both developed and developing countries need to take steps to prevent the negative effects. It is not only in the interests of developing countries to do so, but also in the interests of developed countries, taking into account the interconnectedness of lending in today's globalized financial world (Dissanayake, 2012b, pp. 373-385).

In order to successfully embark on the liberalization and global integration journey, it is important that each developing country understands not only the global situation and conditions, but also evaluates its own internal conditions and adjusts their policies to best suit their individual needs and capabilities.

\section{Concluding remarks and future research}

The lessons from around the world teach us that there is no prescribed way in balancing liberalization and regulatory changes that will guaranty success and lead to high economic growth. They also teach us that it is certain that there will be challenges along the way and that high level of flexibility and education is needed for policy and decision makers in order to readily meet those challenges. The experience from Scandinavia, China, sub-Saharan and other countries transforming from a bank-dominated financial systems to free economy (even from the USA, UK, etc.) are invaluable and should be examined carefully to 
minimize repetition of the same mistakes, which can be very costly (even catastrophic for developping countries).

Developing countries have no other choice but to consider steps towards financial liberalization, which will help to increase capital flows and attract new investments. While there are many deregulating steps that can be considered, developing countries need to remain aware that deregulation affects all sectors of the economy, paying special attention to interactions and flow-on effects that can be caused by changes to their regulatory framework.
The key to success is in determining the appropriate balance between the level of financial liberalization and sufficiently flexible and effective regulatory framework that will support economic growth and maintain investor confidence. The literature provides some great ideas in terms of internal and external measures and actions that can be taken to stimulate liberalization movements. The empirical evidence shows the value of effective regulation, especially proven during economic crisis and shows that liberalization process is not a quick exercise, but rather a long transformation process that requires careful monitoring and management.

\section{References}

1. BCBS (Basel Committee on Banking Supervision). (2010). Basel III: A Global Regulatory Framework for More Resilient Banks and Banking Systems. Basel. Retrieved from: http://www.bis.org/publ/bcbs189.pdf (Accessed: 10/4/2015).

2. Canals, J. (1997). Universal Banking: International Comparisons and Theoretical Perspectives, Oxford: Clarendon Press.

3. Central Bank of Bosnia and Herzegovina. (2006). Annual Report for 2005, Sarajevo.

4. Chandrasekhar, C.P. (2006, 18 March). Financial Liberalisation in India: An Assessment of Its Nature and Outcomes, Economic and Political Weekly, 41 (11), pp. 975-988.

5. Chen, H., Jonung, L. \& Unteroberdoerster, O. (2014). Lessons for China from Financial Liberalization in Scandinavia, Asian Economic Papers, 13 (1), pp. 1-44. Retrieved from: http://dx.doi.org/10.1162/ASEP_a_00246. (Accessed: 10/4/2015).

6. Cooper, J. (2012). Margaret Thatcher and Ronald Reagan: A Very Political Special Relationship, Palgrave Macmillan.

7. Ćirović, M. (2001). Bankarstvo, Beograd: Bridge Company.

8. Dissanayake, A.D. (2012a). Basel III and Emerging Economies: A Critique: Part I, Journal of International Banking Law and Regulation, 27 (9), pp. 353-361.

9. Dissanayake, A.D. (2012b). Basel III and Emerging Economies: A Critique: Part II, Journal of International Banking Law and Regulation, 27 (10), pp. 373-394.

10. Fowowe, B. (2013). Financial liberalization in Sub-Saharan Africa: What do we know? Journal of Economic Surveys, 27 (1), pp. 1-37. Retrieved from: http://dx.doi.org/10.1111/j.1467-6419.2011.00689.x (Accessed: 10/4/2015).

11. Ghosh, J. (2005). The Economic and Social Effects of Financial Liberalization: A Primer for Developing Countries, DESA Working Paper No. 4, UN Department of Economic \& Social Affairs. Retrieved from: http://www.un.org/esa/desa/papers/2005/wp4_2005.pdf (Accessed: 17/6/2015).

12. Kapor, P. (2005). Bankarstvo sa osnovama bankarskog poslovanja i međunarodnim bankarstvom, Beograd: "Megatrend" univerzitet primenjenih nauka.

13. Macey, J.R. (2014). Crony Capitalism: Right Here, Right Now. Yale Law School. Faculty Scholarship Series. Paper 4829.

14. Muzaffar, P. (2008). To What Extent is 'crony capitalism' a Reasonable Explanation for Recent Experiences of the East Asian 'developmental state'? Sussex University.

15. Ocampo, J.A., Jomo, K.S., Khan, S. (2007). Policy Matters: Economic and Social Policies to Sustain Equitable Development, ZED Books Ltd.

16. Quispe-Agnoli, M. (2002). Costs and Benefits of Dollarization, USA: Florida International University, Myriam: Latin America \& Caribean Center, Summit of the Americas Center.

17. Rojas-Suarez, L. (2002). Can International Capital Standards Strengthen Banks in Emerging Markets? Institute for International Economics Working Paper No. 01-10.

18. Thomas, S.Y.H., Palacios, M. \& Stoll, H.R. (2013). Dynamic Financial System: Complexity, Fragility and Regulatory Principles, Financial Markets, Institutions \& Instruments: Topics in Financial Intermediation. New York University Salomon Center, pp. 1-42.

19. Wyplosz, C. (2001). How Risky is Financial Liberalization in the Developing Countries? G-24 Discussion Paper Series, United Nations \& Center for International Development of Harvard University. Retrieved from: http://unctad.org/en/Docs/pogdsmdpbg24d14.en.pdf (Accessed: 16/5/2015).

20. Young, K.L. \& Park, S.H. (2013). Regulatory opportunism: Cross-national patterns in national banking regulatory responses following the global financial crisis, Public Administration, 91 (3), pp. 561-581. Retrieved from: http://dx.doi.org/10.1111/j.1467-9299.2012.02102.x (Accessed: 2/9/2013). 